\title{
Medical negligence under section 304a of the Indian penal code - the need to have a relook
}

\section{Proceeding}

Medical negligence is covered under Tort Law, Consumer Law and Criminal Law. While medical negligence attracts civil liability under Tort and Consumer Law, under Criminal Law, it attracts punishment. While in Torts and Consumer Law, it is a breach of duty, under criminal law it is a state of mind. The basic principle of Criminal Law is that, forbidden act done with an evil mind alone could be offence. However, there are exceptions to this. Strict liability offences and offences which only require negligence are some among them. To explain the term negligence more, two other terms should also be explained intention and recklessness. These terms or equivalent expressions are found in the Indian Penal Code too. They are, intentional, malicious, dishonestly, fraudulently, voluntarily, rash etc. While intention and other expressions clearly mean a state of mind with which a person does something to have the desired result, rashness means a state of mind which though once foresaw the result ignores it and proceeds to do the act. For example, if a person drives a vehicle and kills a person with the intention to kill him, he is said to have done it with intention. However, if a person while taking the vehicle notes that there are some problems with the brake, but still goes with the vehicle and in that drive someone is killed, he cannot be said have the mens rea or intention to kill, but he can be said to have done the act with recklessness. This is a lighter level of guilty mind. A third level is even more lighter which is called negligence, where a person does not even think of the consequence, but his act results in the loosing of life of someone else. Criminal Law punishes the latter two because of the reason that while living in a society one has to be careful, and if one could not reasonably foresee the consequences, or inspite of seeing the consequences one takes a risk and as a result it results in death of others, he is liable to be punished.

In the Indian Penal Code, there is a provision which talks about rash or negligent act, which is used for medical negligence cases as well. These two terms are used as rash and negligent even in the judgments of Supreme Court. ${ }^{1}$ But they are not interchangeable, and instead of 'or' if 'and' is used it makes the terms meaningless. The reason is that, negligence is a state of no-foresee-it is blank as to the consequence, while rash is a state of mind which once foresaw the consequence but ignored it. Both cannot be present in a person simultaneously. To illustrate, suppose a man throws a stone from the tenth floor of a flat without thinking s as to whether someone will be there in the ground. $\mathrm{He}$ is said to have done it negligently. But a person who first thought whether by his act someone will be injured or killed, and still goes ahead with throwing the stone he is said to do it with rashness. How can these two states of mind be present in a single person? Coming to medical negligence also these terms create problems even if used with 'or'. The author here tries to establish that the provision in the Indian Penal Code which deals with rash or negligent act cannot be used for booking doctors for medical negligence, but only for negligence.

${ }^{1}$ See for example Pandit Ukka Kolhe v State of Maharashtra MANU/ SC/0059/1963, State of Punjab v Sourabh Bakshi MANU/SC/0362/2015, State Tr.P.S.Lodhi colony New Delhi v Sanjeev Nanda MANU/0621/2012.
Volume 4 Issue 2 - 2017

\author{
Seema PS \\ Cochin University of Science and Technology, India
}

Correspondence: PS Seema, Assistant Professor, Cochin University of Science and Technology, School of Legal Medicine, Kochi, Kerala, India, Tel 9694963875,Email pss_sls@yahoo.co.in

Received: January 30, 2017| Published: February 15, 2017

The relevant section of the Indian Penal Code is section 304A which reads thus:

\section{a. 304A. Causing death by negligence}

"Whoever causes the death of any person by doing any rash or negligent act not amounting to culpable homicide, shall be punished with imprisonment of either description for a term which may extend to two years, or with fine, or with both."

As was explained above, rash means a person foresees the consequences, and yet goes ahead with an act which will cause the death of a person. If this is applied in the case of doctors, it will mean that if a doctor ever foresaw that death may take place as a result of a treatment or operation, and goes ahead with the operation and if the patient dies as a result, the doctor should be held to be rash! But these kinds of uncertainties about the results are common in treatment as a result of which the hospital authorities get consent of the patients or their relatives before certain treatments or surgery. In that sense, this section cannot be applied at all to doctors for having opted for that particular treatment. Also, the reasonable man concept will create problems in the case of a doctor. What a reasonable doctor should have done is the question. But, if a person approaches a general physician with a heart problem, and if he treats him, his standard will be different from the standard of a cardio specialist. If so, can the general physician be said to have been negligent if the heart patient dies of his treatment, as he could not foresee the consequence due to lack of expertise? Now, if the question is, what if a doctor forgets scissors inside the body of the patient after operation, or operates the left limb instead or right? Are these not clear cases of medical negligence? The answer is, these are clear cases of negligence, but not medical negligence. Because even an ordinary person can say that this is a negligence, which does not require medical knowledge. Medical negligence should mean that only a medical practitioner will be able to say whether there was negligence or not. But, as was said earlier, such a negligence or rashness cannot be covered by this section due to the special nature of the profession. If a professional driver drives a car carelessly, or rashly, and kills another, it is a case of negligence because it is an altogether different profession or occupation. But medical profession is a playing with the lives of the patients very often. 
Patients sometimes come to the doctor on the verge of death. Surgeries or injections can work differently in different persons, despite the due diligence taken by the doctor. The doctor will be foreseeing the death also in many cases, but he chooses the best. So, to take into account the mental state of the doctor as negligent or rash is out of question. So, section 304A cannot be used for dealing with cases of medical negligence. Yet another problem caused by treating medical negligence cases under this section is that the courts are compelled to come with the proposition that "The word 'gross' has not been used in section 304A of IPC, yet it is settled that in criminal law negligence or recklessness, to be so held, must be of such a high degree as to be 'gross'. The expression 'rash or negligent act' as occurring in Section $304 \mathrm{~A}$ of the IPC has to be read as qualified by the word 'grossly'. (Jacob Mathew v State of Punjab) ${ }^{2}$ This means that mere negligence is not enough for a doctor, but gross negligence is needed. Gross negligence is otherwise called as rashness. Thus, while the legislature opted to have both negligent act and rash act alike under section $304 \mathrm{~A}$, the judiciary interpreted it in such a way as to take away one component (negligent) from the section. This has two problems, one is that when negligence itself is a zero state of mind, how can there be further gradation into gross negligence? If the court meant to say that the doctor did not behave at all like a doctor, and showed want of even common sense, it could be called gross negligence, then as mentioned above, it is not a medical negligence, but a mere negligence-which need not be called gross negligence. Thus, it is submitted that while dealing with medical negligence as negligence under section 304A of the Indian Penal Code, the courts will have to have a rethinking as to whether this section can be used for dealing with cases of medical negligence. Otherwise, the courts will have to end up in saying that negligence is not sufficient in the case of medical negligence. They will have to otherwise to hold that in medical negligence, negligence means even the lack of enthusiasm or effort on the part of a doctor in not acquiring the latest method of therapy, which in turn means that if a doctor is not update with his lessons, iron bars are waiting for him!

\section{Acknowledgments}

None.

\section{Conflicts of interest}

None.

${ }^{2}$ MANU/SC/0457/2005 